ISSN:

Print - $2277-0755$

Online - $2315-7453$

(c) FUNAAB 2019

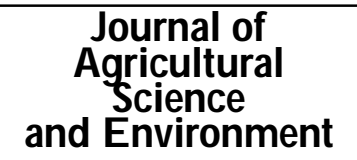

\title{
AMBIENT LEVELS OF GASEOUS, PARTICULATE AND BIO-AEROSOL POLLUTANTS IN FARM SETTLEMENTS ACROSS OGUN STATE, SOUTHWEST NIGERIA
}

\author{
${ }^{* 1}$ F. F. OYEBANJI, 2G.R.E.E., ANA, 3Y. MIJINYAWA AND IY. A. TIJANI \\ 1 D epartment of Environmental Management and Toxicology, Federal University of \\ Agriculture, Abeokuta Nigeria \\ 2D epartment of Environmental Health Sciences, Faculty of Public Health, University \\ College Hospital, University of Ibadan, Ibadan, Nigeria \\ 3D epartment of Agricultural and Environmental Engineering, Faculty of Technology, \\ University of Ibadan, Ibadan
}

*Comesponding Author: oyebanjiff@ funaab.edu.ng Tel: +2348066513400

\begin{abstract}
ABST RACT
This study assessed the levels of air pollutants emitted outdoor of farm settlements (FS), the seasonal and temporal variations, and the relationship among the parameters monitored. Seven FS within Ogun State were investigated, with 211 sampling points established across the FS. The concentrations of VOCs, $\mathrm{SO}_{2}, \mathrm{NO}_{2}, \mathrm{CO}, \mathrm{O}_{3}, \mathrm{NH}_{3}, \mathrm{CO}_{2}, \mathrm{TSP}, \mathrm{PM}_{2.5}$ and $\mathrm{PM}_{10}$ were monitored in replicates using active potable samplers while bacteria and fungi were isolated using settle plate technique. Descriptive (means and standard deviation) and inferential statistical tools (Pearson correlation) were used to analyse the data. The mean ranges of VOCs, $\mathrm{CO}$ and $\mathrm{CO}_{2}(\mathrm{ppm}) ; 20.8 \pm 10.53-48.67 \pm 19.05$, $17.95 \pm 6.65-21.5 \pm 3.93,3562.15 \pm 1200.85-4266 \pm 1176.85$, and for bacteria and fungi (cfu/m 3 ); $548.98 \pm 1.18-2255.01 \pm 1.27$ and $525.68 \pm 1.15-1282.38 \pm 1.27$ respectively were above the threshold limits. There were significant seasonal, spatial and temporal differences among observed means of VOCs, $\mathrm{CO}_{2} \mathrm{O}_{3}$, TSP, $\mathrm{PM}_{2.5}$, and fungi. The bacteria and fungi count increased as TSP, $\mathrm{PM}_{2.5}$ and $\mathrm{PM}_{10}$ increased. The study established that levels of air pollutants are dependent on the type of farming practice.
\end{abstract}

Keywords: Agriculture, Outdoor, Air pollutants, Bio-aerosols, Farm settlements.

\section{INTRODUCTION}

Extensive agricultural processes involve deforestation, slashing and burning, fertilization, the introduction of agrochemicals, vaccines, antibiotics, antimicrobials, processing and packaging of farm produce for sale (Bhandari, 2014) and mostly from bad farming practices (Harizanova-Bartos and Zornitsa Stoyanova, 2018). At some instances, massive mechanization and labour may be included. According to Rohila $\&$ al. (2017), farming has a more significant impact on the environment than any other single human activity. Hinz (2002) reported that agriculture is the source of various materials that can affect all compartments of the ecosystem (air, water, soil, plants and humans), while at the same time acting as the receptor of many contaminants from different environmental sources. The nexus that exists between agriculture and the environment is 
highly sophisticated than typically predicted in chain-emission exposure and impact transmission. Aneja et al. (2009) reported that in the United States, agricultural emissions play an essential role in multiple environmental and public health issues processes with consequent impact on local and regional environmental quality. Nevertheless, Jager (2005) and Arslan and Aybek (2012) identified significant hazards resulting from organic and inorganic particulates, contaminants, pollutants, and infectious agents (including public health concerns from the burden of bio-aerosol emissions from farm buildings). Seedorf (2004) believed that these emissions play critical roles in respiratory disorders in those living near animal industries, which can be transmitted from and via animal houses (Schulz \&al., 2005).

FAO (2015) noted the global impacts of fire land clearing, plant residue burning; livestock methane; fertilizer and manure nitrous oxide; and manure and urine ammonia, which caused air pollution in tropical regions far from the emission sources. The studies of D ungan (2010) and Samadi $\&$ al. (2013) on different agricultural activities, especially animal husbandry and veterinary practices with particular reference to atmospheric pollutants including microorganisms transport through the air have confirmed occupational risk to farmers residing around livestock buildings for pig, cattle and poultry farms (Eisenberg $\notin$ al, 2010; Sowiak $\&$ al., 2011; Brodka \& al., 2012).

Hence, with the recent trend in the outbreak of air-related diseases especially those of animal origin, and consistent lowering in living standards, there is the need to assess the levels of air pollutants in farm settlements. Since previous studies have indicated probable air pollutants related to agricultural systems and activities, this study identified the specific agricultural activities in each FS, monitored outdoor air pollutants levels and relate such pollutants to the main agricultural practice in the specific FS.

\section{MATERIALS AND METHODS Description of the study area}

Ogun State was created in 1976 and located in the Southwest region of Nigeria. It borders Lagos State to the South; Oyo and Osun States to the North; Ondo to the Southeast; and the Republic of Benin to the Northwest, and lies on latitude $7^{\circ} 00^{\prime} \mathrm{N}$ and longitude $3^{\circ} 35^{\prime} \mathrm{E}$. Abeokuta is the capital and the largest city in the State. The total population of 3,751,140 residents was registered in 2006, comprising 1,864,907 males and 1,886,233 females (NPC, 2006) occupying a land area of $16,409.26 \mathrm{~km}^{2}$. The State is blessed with a favourable climate and good vegetation throughout the year with evergreen forest vegetation and soil suitable for growing cash and food crops such as oil palm, rice, kola nut, cocoa, cassava, cocoyam and vegetables in the southern part of the State; while in the north, there is a large savannah region suitable for animal husbandry (O GSG , 2017). There are eight farm settlements distributed across the State. These include Ado-Odo, Ago-Iwoye, Ajegunle, Coker, Ibiade, Ikenne, Ilewo-O rile, and Sawonjo. All the FS except Ilewo-Orile were selected for this study (Figure 1) because as at the time of this study, the Ilewo-Orile FS was not in operation. 


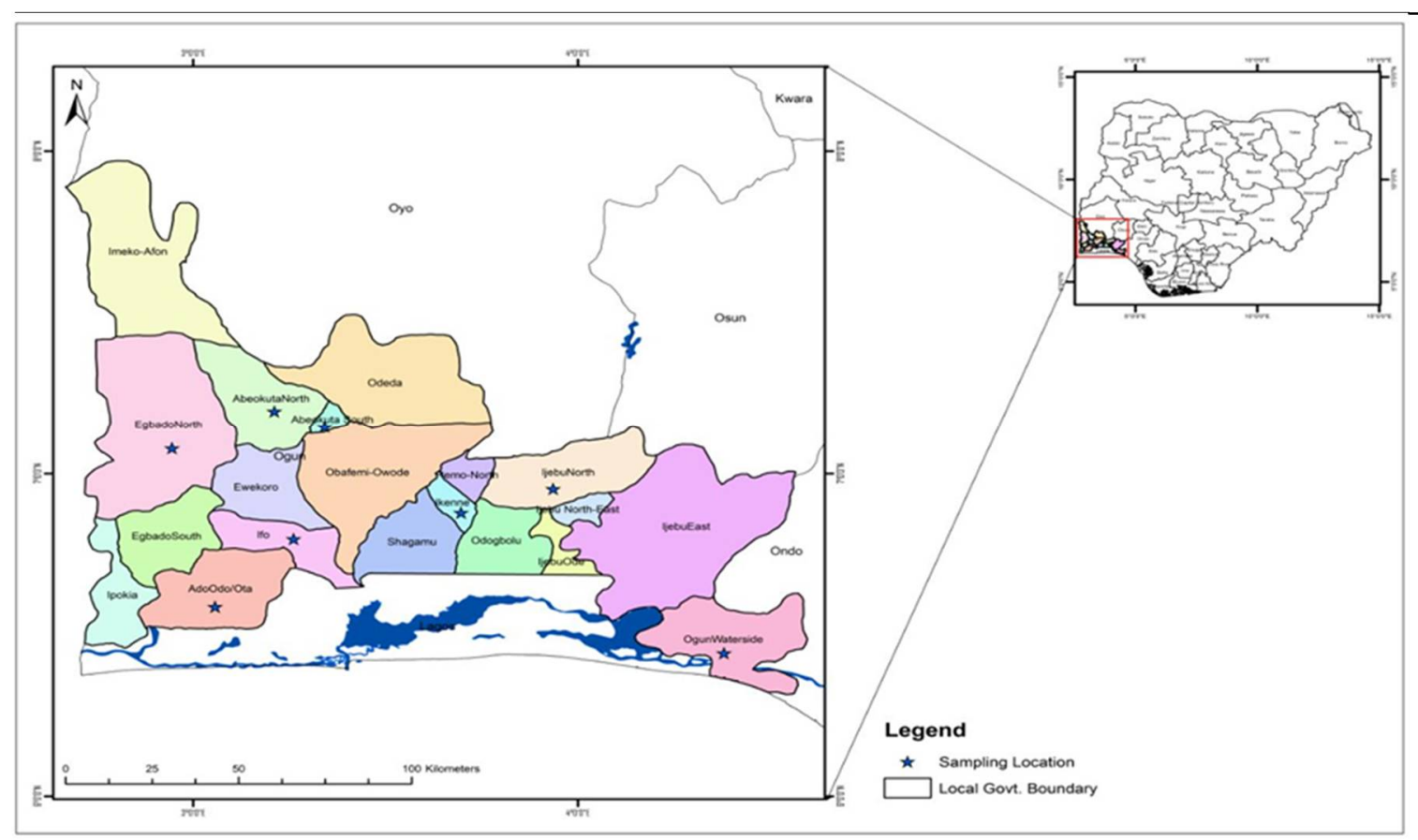

Fig. 1: Map of 0 gun state showing the locations of selected farm settlements

\section{Sources and types of data}

In this study, both secondary and primary data sources were employed. Secondary data was collected from Farm Officers employed by the $\mathrm{O}$ gun state government, and it included all necessary and available information about each farm settlement. In contrast, the primary data sources included information collected through observation, field measurements and laboratory analysis concerning the objectives.

\section{On-site observation}

A walk-through and on-site physical observation of the FS was carried out to ascertain the information given by the Farm officers on the type of agricultural activities.

\section{Air quality monitoring}

Air quality monitoring was conducted for the dry season (D ecember 2017 and February 2018), wet season (May and July 2018); between 8 am - 10 am for morning and 5 pm - 7 pm for the evening samplings. Measurements were taken at 5 minutes intervals during the two-hour monitoring. Active hand-held in-situ samplers were used for both the gaseous pollutants and PM monitoring. The Thermo Scientific MIE pDR1500 model particulate counter has three cyclones specific for each particle size (TSP, $\mathrm{PM}_{10}, \mathrm{PM}_{2.5}$ ) cut-off. Each of the parameters was monitored after changing the filter paper to take a new reading at different sampling points. The equipment was adequately set-up before sampling to ensure the accuracy of the readings displayed.

\section{Bioaerosol sampling}

Two types of solid media - Nutrient Agar (NA) for bacteria and Potato D extrose Agar (PDA) for fungi were prepared according to manufacturer's specifications and poured into labelled $92 \mathrm{~mm}$ Petri dishes. The NA 
was enriched with glucose, and PDA was supplemented with antibiotics to inhibit the growth of unwanted organisms). These media were left open for 30 minutes for gravity settling/ collection (sedimentation/ open plate) of bioaerosol at the height of $1 \mathrm{~m}$ from the floor and at a distance of about $1 \mathrm{~m}$ from the wall or any object as described in Napoli \& al. (2012). The main precaution taken during the sampling time was to avoid talking, sneezing and walking. The dishes' lids were replaced at the end of the exposure period. The plates were transported in a clean container to the laboratory and incubated at $37^{\circ} \mathrm{C}$ for $18-24$ hours for bacteria and $27^{\circ} \mathrm{C}$ for $48-72$ hours for fungi (Wemedo $\&$ al., 2012). The number of colonies expressed as CFU m ${ }^{-3}$ was calculated by using the Koch's sedimentation method of Settle Plate Technique (Polish standard 89/ Z04008/ 08) described by StryjakowskaSekulska \& al. (2007) and Morakinyo \& al. (2015).

\section{M ethods of data analysis}

Data were manipulated for descriptive and inferential statistical analysis. D escriptive statistics such as mean \pm standard deviation (SD) and range were used to summarize data. Inferential statistics observed were analysis of variance to identify significant variations, $t$-test to test for variation between seasons and time of monitoring and Pearson correlation matrix to assess the relationships among monitored parameters during the different seasons at both 0.01 and 0.05 confidence levels.

\section{RESULTS Agricultural activities across the FS}

In terms of land area the FS are in this order Ado-Odo > Ibiade > Ago-Iwoye $=$ Sawonjo > Ikenne >Ajegunle > Coker. The Coker FS, which has the least land area, has the highest number of settlers. AdoO do, Sawonjo and Coker FS deal majorly in crops especially cassava and other staple crops. The settlers in Ado-O do and Ikenne FS also deal with cash and tree crops like cocoa, rubber and timber. Palm oil production is common at Ado-Odo, Sawonjo and the largest scale is at Ibiade. Considering animal production, the largest scale of poultry production is at Ikenne, while the largest piggery production is at Ajegunle and small scale piggery is at Ago-Iwoye.

\section{Gaseous pollutants levels}

The mean values for gaseous pollutants across the FS are presented in Table 2. The highest concentrations for VOCs (48.67 $\pm 19.05 \mathrm{ppm})$ and $\mathrm{NH}_{3} \quad(0.44 \pm 0.27$ ppm) were observed at Ikenne, for $\mathrm{NO}_{2}$ $(0.13 \pm 0.24 \mathrm{ppm})$ at Ajegunle, $\mathrm{CO}_{2}$ $(4266 \pm 1176.85 \mathrm{ppm})$ and $\mathrm{SO}_{2}(0.02 \pm 0.08$ $\mathrm{ppm})$ at Sawonjo, and for CO (21.5 \pm 3.93 ppm) was at Ibiade. The maximum limits of FEPA (1991) for VOCs, and WHO (2005) for CO, and ASHRAE (2010) for $\mathrm{CO}_{2}$, were exceeded at all the sampled locations. However, only Ikenne exceeded the limit of FEPA (1991) for $\mathrm{NH}_{3}$. There are significant variations among the values recorded across the locations at different sites of monitoring for VOCs at $p<0.05$. The seasonal levels of gaseous pollutants (Table 3 ) shows that the highest for $\mathrm{VOCs}, \mathrm{CO}$, and $\mathrm{CO}_{2}$ were observed during the wet season while the highest $\mathrm{NH}_{3}$ was recorded during the dry season. It was also noted that there were significant variations ( $p>0.05)$ in the means of VOCs, $\mathrm{CO}_{2}, \mathrm{O}_{3}$ and fungi across the season. Table 4 shows the concentration of pollutants between the time of monitoring. VOCs, $\mathrm{NH}_{3}$, and $\mathrm{NO}_{2}$ displayed the highest values in the morning while $\mathrm{CO}$ and $\mathrm{CO}_{2}$ displayed the highest in the evening. A significant difference was observed only in the means of $\mathrm{O}_{3}$. 
AMBIENT AIR POLLUTANTS IN FARM SETTLEMENTS...

PM pollutants levels

The highest particulates levels across the FS (Table 2) for TSP $\left(47.05 \pm 24.09 \mu \mathrm{g} / \mathrm{m}^{3}\right)$ was at Ikenne, while for $\mathrm{PM}_{10}(18.31 \pm 12.6 \mu \mathrm{g} /$ $\left.\mathrm{m}^{3}\right)$ and $\mathrm{PM}_{2.5}(17.43 \pm 8.6 \mathrm{ppm})$ were at Coker. There are significant variations among the values recorded across the locations at different sites of monitoring for TSP, $\mathrm{PM}_{10}, \mathrm{PM}_{2.5}$ at $\mathrm{p}<0.05$. Table 3 shows that the highest particulate matter levels were observed during the dry season. Besides, the temporal concentrations of PM (Table 4) shows that TSP and $\mathrm{PM}_{2.5}$ displayed the highest in the evening while $\mathrm{PM}_{10}$ had the highest in the moming. There was no significant temporal variation among the average values of particulate matter measurements. Tables 5 and 6 present the relationships among the parameters during the wet and dry seasons, respectively. The associations observed during the dry season were significant and positive but low. The strong positive and significant correlations were among TSP and $\mathrm{PM}_{10}\left(\mathrm{r}^{2}=\right.$ 0.822; $\mathrm{p}<0.01)$ and TSP and $\mathrm{PM}_{2.5}\left(\left(\mathrm{r}^{2}=\right.\right.$
$0.909 ; \mathrm{p}<0.01)$, TSP and Bacteria( $\left(\mathrm{r}^{2}=0.310\right.$; $\mathrm{p}<0.01$ ) during the dry season.

\section{Bioaerosol pollutants levels}

The highest Bacteria $(225.01 \pm 1.27 \mathrm{CFU} /$ $\left.\mathrm{m}^{3}\right)$, and fungi $\left(1282.38 \pm 1.27 \mathrm{CFU} / \mathrm{m}^{3}\right)$ were recorded at Ikenne (Table 2); also, all the locations had bacteria and fungi loads above the threshold of AIHA (2001) of $500 \mathrm{cfu} /$ $\mathrm{m}^{3}$. There were significant differences in the mean values of fungi across the FS at $p<$ 0.05 . The highest bacteria and fungi were observed during the wet season (Table 3). There are significant seasonal variations among the mean values recorded in fungi load at $p<0.05$. Table 4 shows that bacteria and fungi displayed the highest in the evening. There was no significant temporal difference observed in the mean bioaerosol load. Figures $2-4$ show a directly proportional relationship among particulate components and bio-aerosol load. In other words, the higher the concentration of TSP, $\mathrm{PM}_{10}$ and $\mathrm{PM}_{2.5}$, the higher the bacteria and fungal load. 
Table 1: Major crops and activities in FS

\begin{tabular}{|c|c|c|}
\hline Local Govt & FS & Observation and Information \\
\hline Ado-Odo & Ado-Odo & $\begin{array}{l}\text { The Ado-O do FS is situated within the Ado-O do/O ta } \\
\text { Local Government (LG ) on } 6^{\circ} 41^{\prime} \mathrm{N} 3^{\circ} 41^{\prime} \mathrm{E} \text {. This FS is } \\
\text { the largest with about } 3190 \text { hectares of land and about } \\
100 \text { houses. The settlers' deal majorly in crop produc- } \\
\text { tion such as cocoa, kola nut, palm oil, cassava, timber, } \\
\text { maize and vegetables with small scale animal produc- } \\
\text { tion. }\end{array}$ \\
\hline Ikenne & Ikenne & $\begin{array}{l}\text { The Ikenne FS is situated within the Ikenne LG on } 6^{\circ} \\
52^{\prime} \mathrm{N} 3^{\circ} 43^{\prime} \mathrm{E} \text {. This FS has about } 835 \text { hectares of land } \\
\text { and about } 22 \text { houses. The settlers' deal in poultry pro- } \\
\text { duction on a very large scale and rubber plantation. }\end{array}$ \\
\hline Ago-Iwoye & Ago-Iwoye & $\begin{array}{l}\text { The Ago-Iwoye FS is situated within the Ijebu North } \\
\text { LG on } 6^{\circ} 57^{\prime} \mathrm{N} 4^{\circ} 00^{\prime} \mathrm{E} \text {. This FS has about } 1508 \text { hectares } \\
\text { of land and about } 52 \text { houses. The settlers' deal in large } \\
\text { scale Cassava production with medium-scale poultry } \\
\text { and piggery production. }\end{array}$ \\
\hline Y ewa North & Sawonjo & $\begin{array}{l}\text { The Sawonjo FS is situated within the Y ewa North LG } \\
\text { on } 7^{\circ} 14^{\prime} \mathrm{N} 3^{\circ} 02^{2} \mathrm{E} \text {. This FS has about } 1508 \text { hectares of } \\
\text { land and about } 62 \text { houses. The settlers' deal in large } \\
\text { scale Cassava production with medium scale palm oil } \\
\text { production. }\end{array}$ \\
\hline $\begin{array}{l}\text { O gun Water- } \\
\text { side }\end{array}$ & Ibiade & $\begin{array}{l}\text { The Ibiade FS is situated within the } 0 \text { gun Waterside } \\
\text { LG on } 7^{\circ} 00^{\prime N} 3^{\circ} 35^{\prime} \mathrm{E} \text {. The LG is a coastal and bound- } \\
\text { ary community. This FS has about } 1600 \text { hectares of } \\
\text { land and about } 35 \text { houses. The settlers' deal in large } \\
\text { scale cassava and other seasonal crops with extremely } \\
\text { large scale palm oil production. }\end{array}$ \\
\hline $\begin{array}{l}\text { Abeokuta } \\
\text { South }\end{array}$ & Ajegunle & $\begin{array}{l}\text { The Ajegunle FS is situated within the Abeokuta Soth } \\
\text { LG on } 7^{\circ} 9^{\prime} 39^{\prime \prime N} 3^{\circ} 20^{\prime} 54^{\prime \prime} \mathrm{E} \text {. This FS has about } 497 \\
\text { hectares of land and about } 63 \text { houses. The settlers' deal } \\
\text { in large scale cassava and other seasonal crops with } \\
\text { large scale piggery. }\end{array}$ \\
\hline Ifo & Coker & $\begin{array}{l}\text { The Coker FS is situated within the Ifo LG on } 6^{\circ} 49^{\prime} \mathrm{N} \\
3^{\circ} 12^{\prime} \mathrm{E} \text {. This FS has about } 473 \text { hectares of land and } \\
\text { about } 120 \text { houses. The settlers' deal in large scale Cas- } \\
\text { sava and other seasonal crops. }\end{array}$ \\
\hline
\end{tabular}




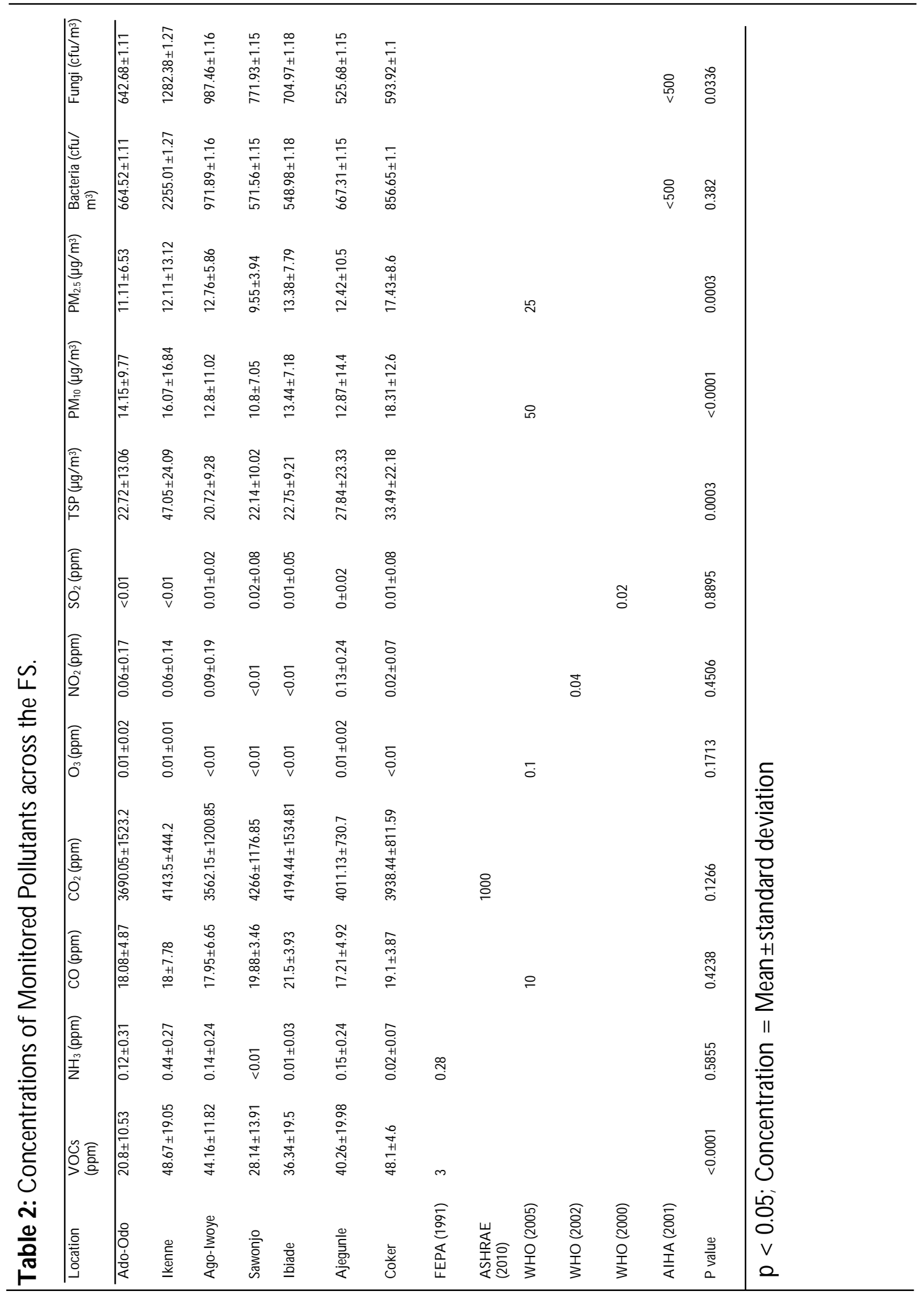




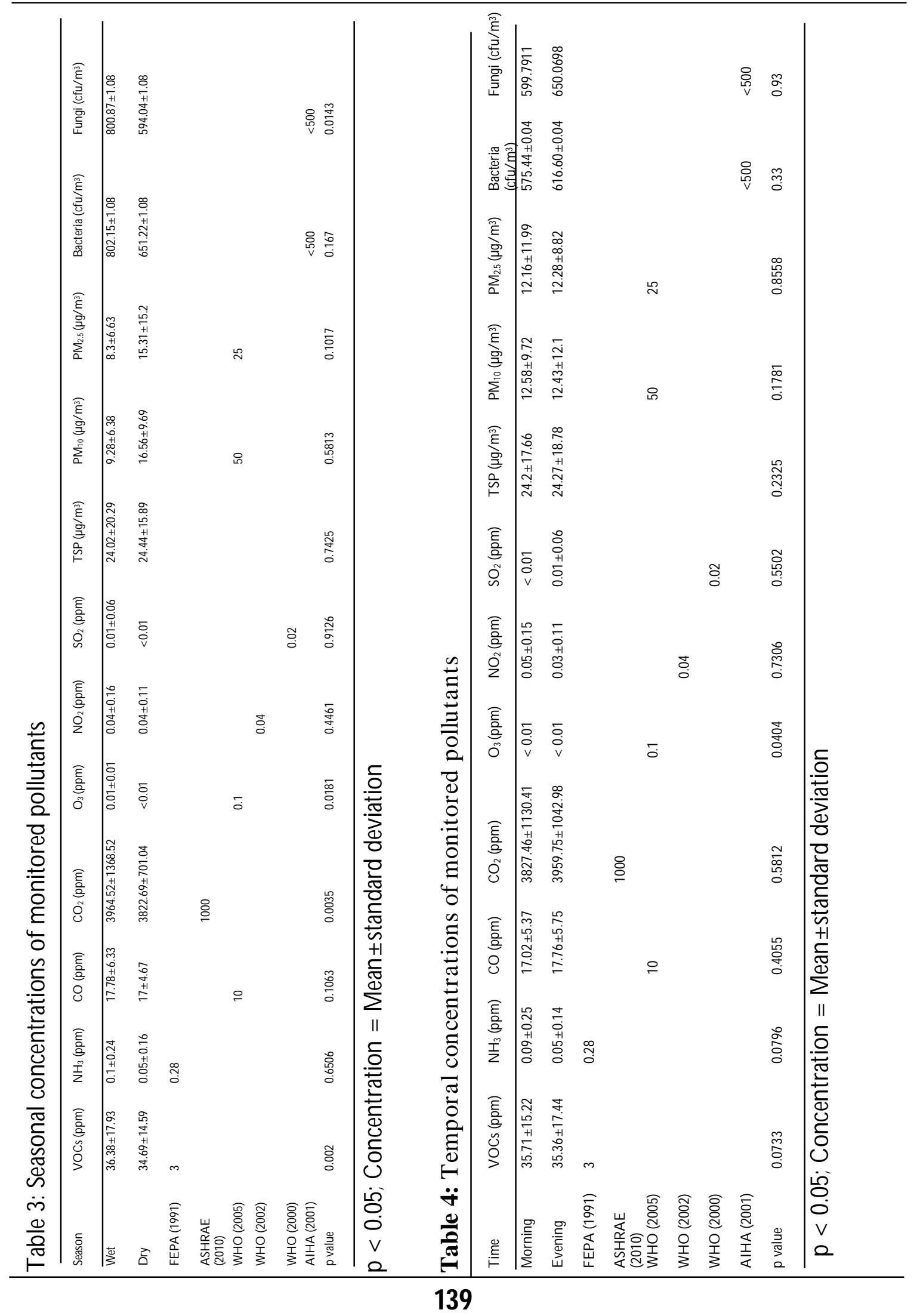




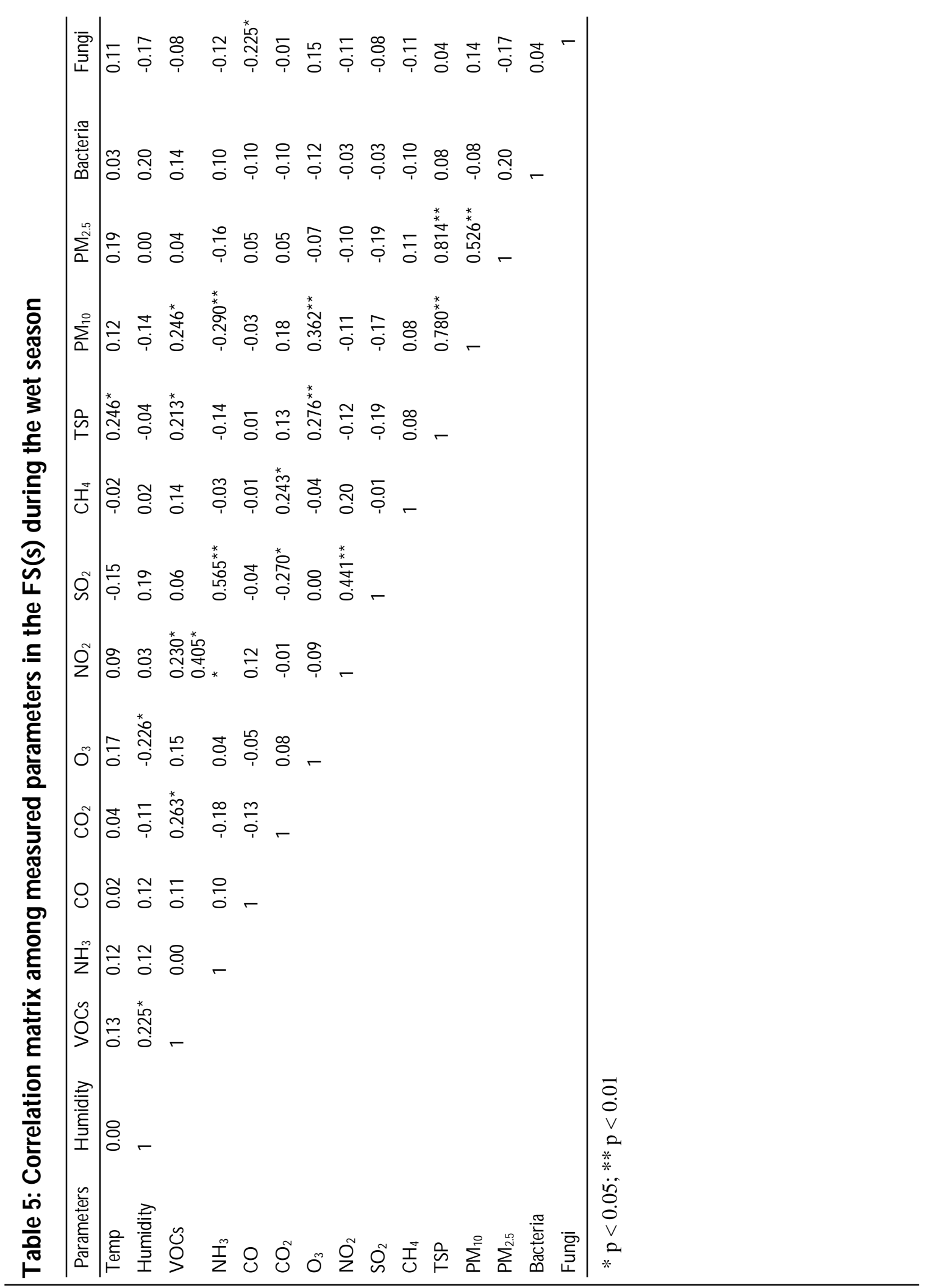




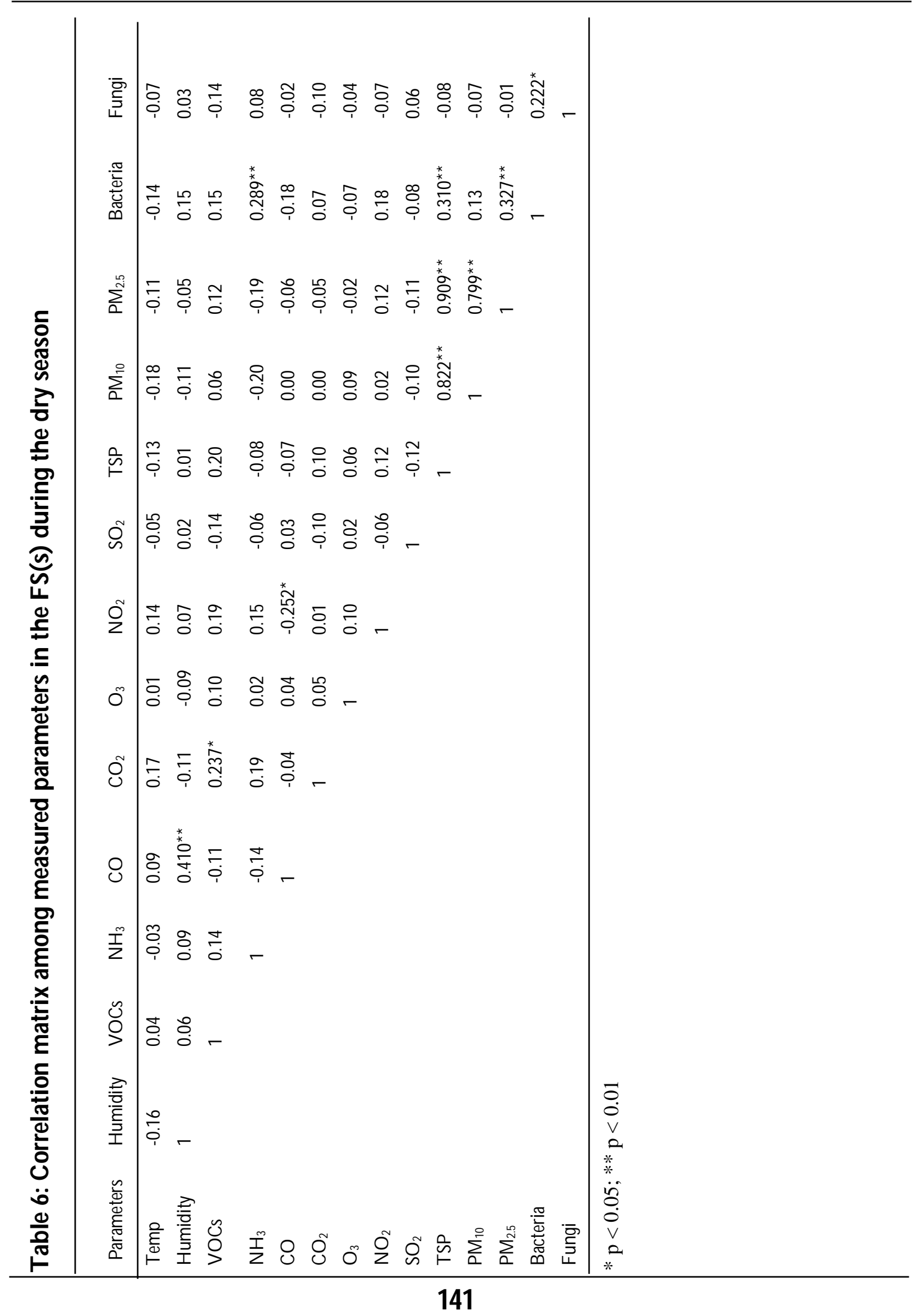




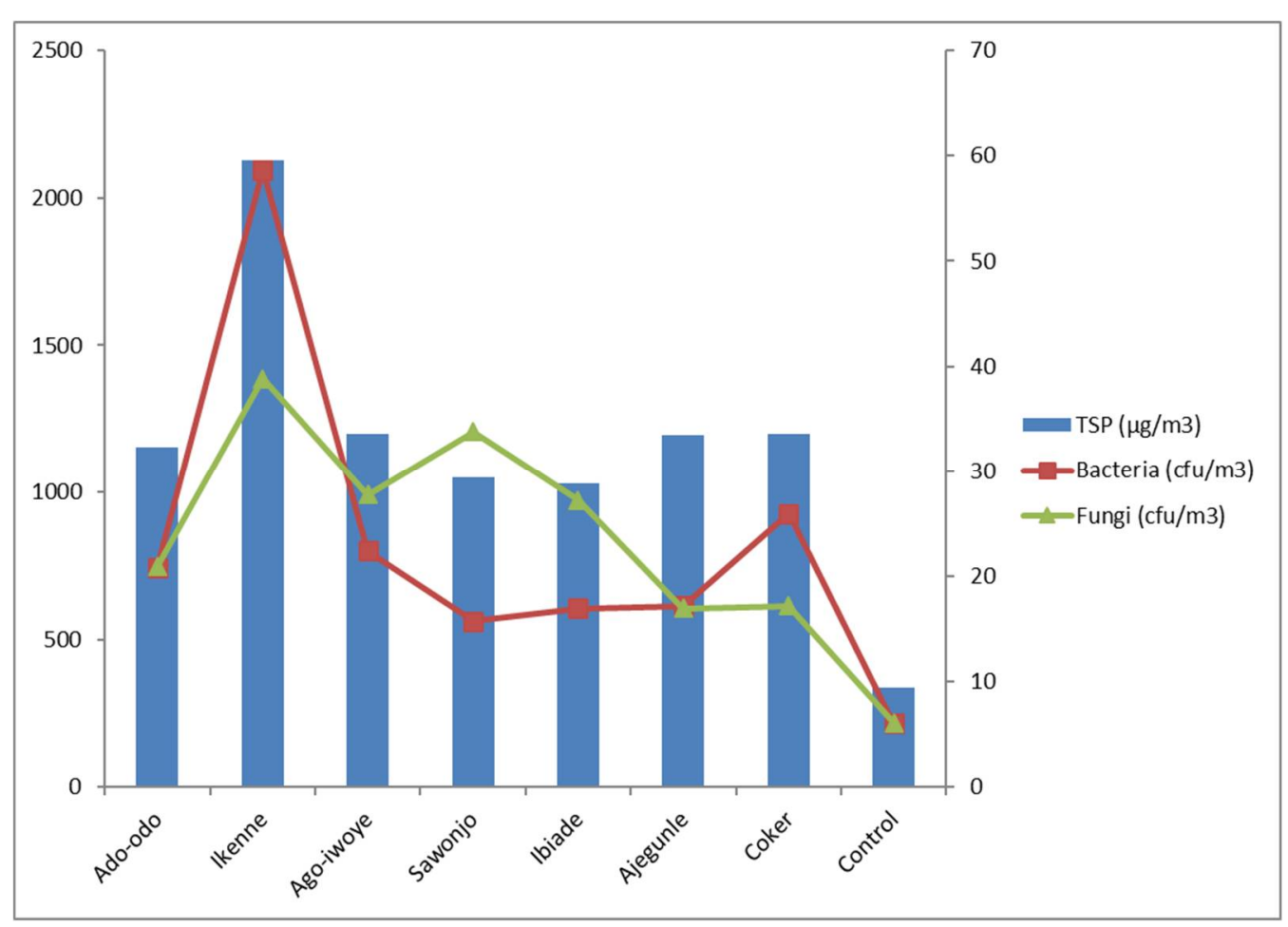

Fig. 2: Relationship among concentration of TSP, bacterial and fungal load

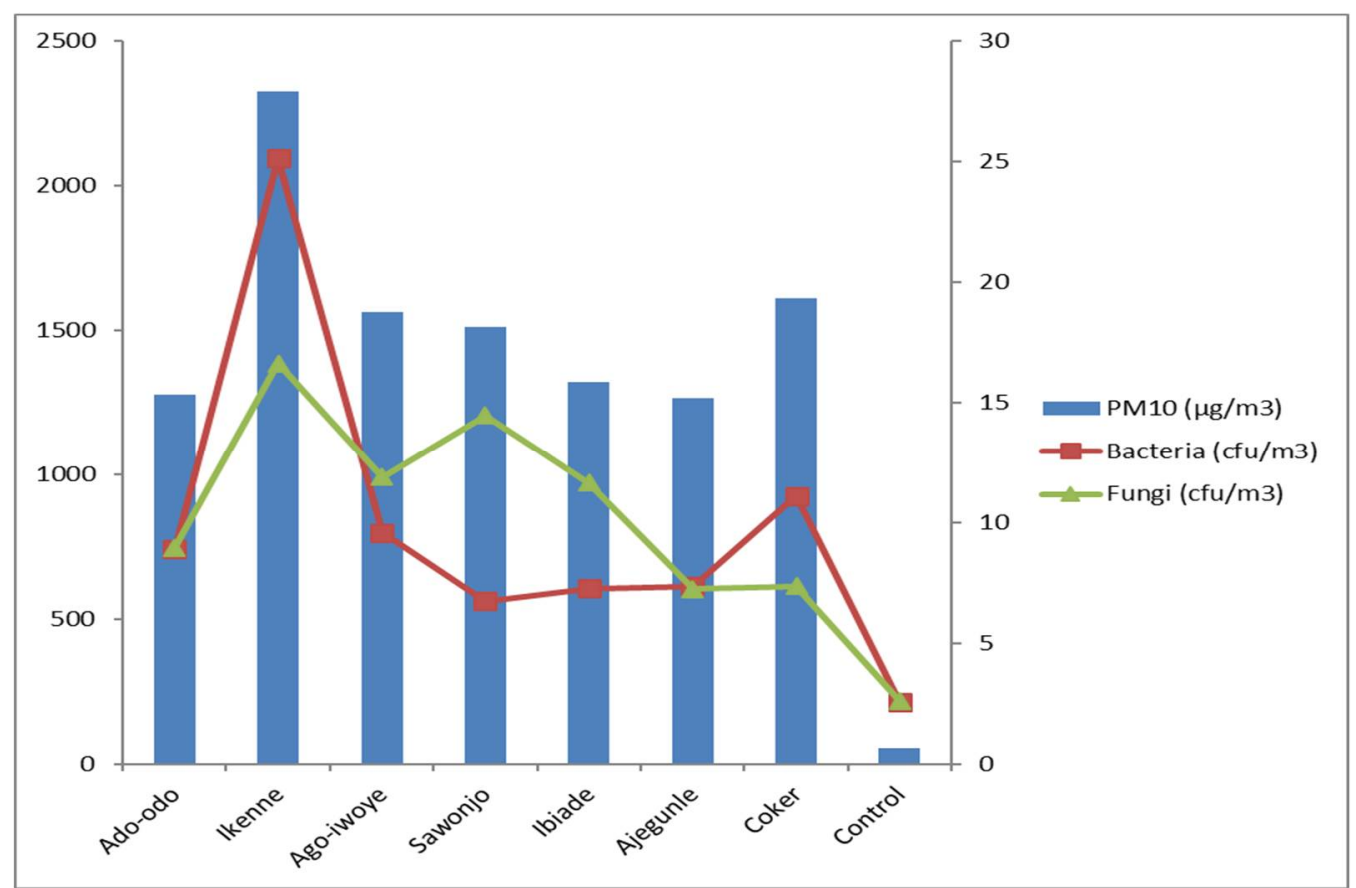

Fig. 3: Relationship among concentration of $\mathrm{PM}_{10}$, bacterial and fungal load 


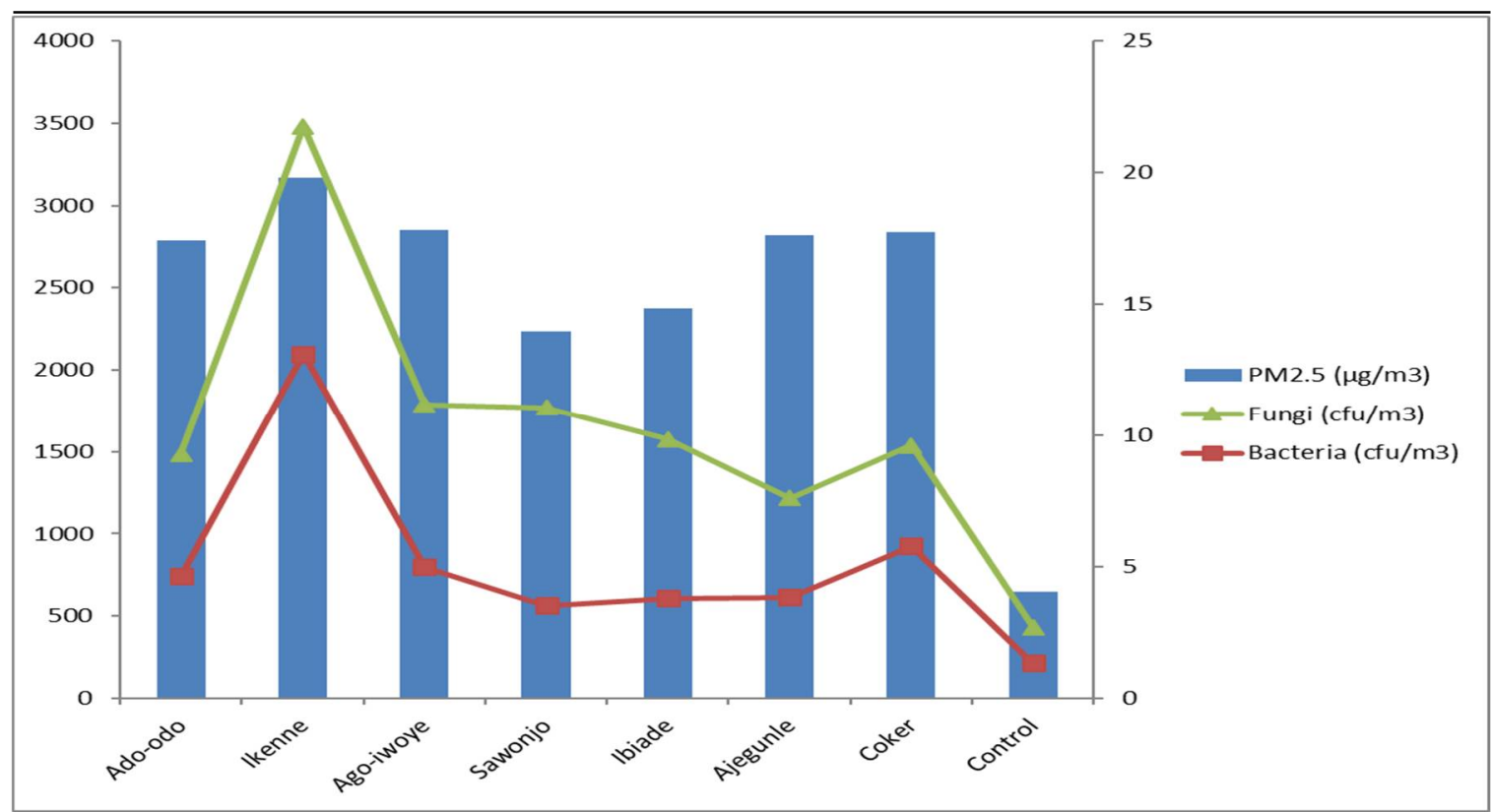

Fig. 4: Relationship among concentration of $\mathrm{PM}_{2.5}$, bacterial and fungal load

\section{DISCUSSION}

The various sites have peculiarities in location, the predominant agricultural activities and different kinds of emissions observed. Ajegunle FS is situated close to the express road with a nearby quarry site and heavyduty trucks in and out of the quarry sites increasing the vehicular gaseous emission in the FS. Important gases produced from vehicular emissions are VOCs, TSP, $\mathrm{SO}_{2}$, $\mathrm{NO}_{2}$ and $\mathrm{CO}$, which can have adverse effects on the exposed population (Ingle $\&$ al., 2005). VOCs are critical surface ozone precursors (Li \& al., 2017). Ibiade is characterized by large scale palm oil productions that require burning of wood for fuel. Wood burning is a dirty cooking energy source which produces elevated concentrations of $\mathrm{CO}_{2}, \mathrm{NO}_{2}$ and $\mathrm{CO}$ in the indoor and outdoor environment. According to O himain and Izah (2013), palm oil production requires boiling and digestion activities. Ibiade being a border town and very close to waterfronts, has the tendency of increased humidity which support the growth of fungi as corroborated by the findings of Afzal \& al. (2004).

Ikenne is a very small FS and highly congested, in addition to storage of poultry feed indoor and nearby scattered animal houses. These observations further justified the elevated concentrations of $\mathrm{TSP}, \mathrm{PM}_{10}$ and $\mathrm{PM}_{2.5}$ which is in line with the studies of $\mathrm{Xu}$ \& al. (2016) in China; Winkel $\notin$ al. (2016) in the Netherlands and Mostafa $\&$ al. (2016) in Germany. High $\mathrm{NH}_{3}$ concentrations were also reported outdoors, possibly due to large -scale animal husbandry, which is known to account for most of the total emissions of ammonia. The highest level of pollutions from the agricultural sector is by methane, ammonia and carbon dioxide (HarizanovaBartos and Zornitsa Stoyanova, 2018). Am- 
AMBIENT AIR POLLUTANTS IN FARM SETTLEMENTS...

monia is released majorly from the birds through the excretion of unused nitrogen in the form of $80 \%$ uric acid, $10 \%$ ammonia, and $5 \%$ urea (Karimi, 2017). Ammonia gas reacts with moisture to form a simple, corrosive solution called ammonium that can damage birds and humans by corroding the respiratory tract of chickens, thereby paralyzing or even destroying the epithelial cells. Under such conditions, the cilia can not clear the mucus on the mucosal surface of the trachea and thus trapping bacteria, entering the lungs or air sacs and causing infection (Karimi, 2017). High bacteria load in Ikenne is probably as a result of the intense animal husbandry as corroborated by Zucker \&al. (2000) who reported diverse bacteria isolated in animal houses; and presence of animal pets especially dogs increase the bacterial load (D unn $\boldsymbol{\notin}$ al., 2013). According to Harizanova-Bartos and Zornitsa Stoyanova (2018), the biggest environmental polluters in livestock husbandry are cattle-breeding, buffalo-breeding, the pig sector, sheep and goat farming. It appears that three locations (Ikenne, Ago-Iwoye and Ajegunle) where extensive and large scale animal husbandry is predominant showed increased outdoor bacterial concentration, while fungal concentration reduced in the outdoor relative to indoor. In the urban areas, the presence of factors of globalization; industrialization and transportation have been studied extensively and proven as the significant sources of air pollutants (Power \& al., 2014). These factors are relatively absent in rural areas, although there exist other activities which tend to emit and increase the ambient concentration of air pollutants (Oyebanji $\&$ al., 2016). The global health burden from air pollutions falls largely on the rural populace (Karambelas \& al., 2018) where agriculture is the predominant occupation.
Higher concentrations of $\mathrm{CO}_{2}$ exceeding the ASHRAE (2010) permissible limit across all monitored locations, seasons, time and site (indoor/ outdoor) is probably due to indirect emissions from deforestation and land cultivation and soil preparation (Gilbert, 2012). $\mathrm{CO}_{2}$ are likely to impact global climate and the growth, biology, and chemistry and metabolism of plants (D usenge $\&$ al., 2019).

The location-based analysis revealed that CO concentrations at all the farm settlements exceeded that threshold limit. This might not be unconnected to the various household cooking activities (Oyebanji \& al., 2013); slashing and burning of unwanted plants (Rohila \& al., 2017) and tractors usage (Rashid \& al., 2013). CO is a noxious gas whose existence affects the levels of other greenhouse gases including carbon dioxide, methane and tropospheric ozone by interacting easily with the hydroxyl radical $(\mathrm{OH})$ to form stronger greenhouse gas $\mathrm{CO}_{2}$ ).

Considering particulate matter concentration, only Ikenne exceeded the $\mathrm{PM}_{2.5}$ threshold limit.

Due to the ability of $\mathrm{PM}_{2.5}$ to penetrate unfiltered into the lungs and blood vessels, inhalation of this fine particulate matter can cause severe respiratory disease and heart disease aggravating disease, leading to irreversible DNA mutations, heart attacks and subsequent death (Ojekunle $\notin \mathrm{al}$, , 2018). The study by Raaschou-Nielsen et al. (2013) across seventeen European countries showed a significant association between risk for lung cancer, $\mathrm{PM}_{10}$ and $\mathrm{PM}_{2.5}$.

The relationship recorded among the particulate matter (TSP, $\mathrm{PM}_{10}$ and $\mathrm{PM}_{2.5}$ ) and bioaerosols (bacteria and fungi) clearly show that the contents of particles are diverse. Alt- 
hough the pathogenicity of the bacteria and fungi isolated was not determined, Kalisa $\&$ al. (2019) already ascertained that significant and dominant fractions of airborne PM are bio-aerosols. Similarly, bio-aerosol levels are usually determined by the levels of particulate matter as reported by Grzyb \& Lenart-Boroń (2019).

\section{CONCLUSION}

This study monitored the ambient concentration of gases, particulates matter and bioaerosol load within farm settl\#ements during the wet and dry seasons respectively, including the morning and evening. The burden of gaseous and particulate pollutants was assessed using potable hand-held active air samplers while bio-aerosols were isolated following gravity settling and standard plate -count procedure. The mean concentrations of VOCs, $\mathrm{CO}_{2}, \mathrm{CO}$, bacteria and fungi across all the sampled locations were above the standard threshold, while only Ikenne exceeded the standards $\mathrm{NH}_{3}$. There were significant positive relationships among the PM microns monitored and bio-aerosol concentration. The levels of air pollutants varied across the FSs due to the different farming expertise across the settlements. Gaseous pollutants were higher in FS with extensive crop farming and processing while particulate matter and bio-aerosols were relatively higher in FS with extensive animal husbandry and related activities. Farmers should be advised to protect themselves with the use of nose mask against direct inhalation of air pollutants during their daily work. There is a need to reduce burning activities, locate farm produce processing generating air pollutants away from the residences and maintain proper hygiene practices when handling animals.

\section{REFERENCES}

Afzal, M., Mehdi, F.S., Siddiqui, Z.S. 2004. Effect of relative humidity and temperature on airborne fungal allergens of Karachi city. Pakistan Journal of Biological Sciences 7:159 $-162$

American Industrial Hygiene Association (AIHA) 2001. Indoor environmental quality committee the practitioner's approach to indoor air quality investigations. Proceedings of the indoor air quality international

Aneja, V.P., Schlesinger, W.H., Enisman, J.W. 2009. Effects of agriculture upon the air quality and climate: Research, policy and regulations. Environmental Science and Technology 43(12):4234-4240

Arslan, S., Aybek, A. 2012. Particulate Matter Exposure in Agriculture. Intech0pen 10:73-104

ASHRAE limits ANSI/ ASHRAE Standard 62-2001, 2010. Ventilation for acceptable indoor air quality standard 62.1. United States of America

Bhandari, G. 2014. An overview of agrochemicals and their effects on the environment in Nepal. Applied E cology and E nvironmental Sciences 2(2), 66-73.

Brodka, K., Sowiak, M., Kozajda, A., Cyprowski, M., Szadkowska-Stanczyk, I. 2012. Biological contamination in office buildings related to ventilation/ air conditioning system. Medycyna Pracy 63(3):303-315

Cyrys, J., Pitz, M., Bischof, W., Wichmanna, H., Heinnicha, J. 2004. Relationship between indoor and outdoor levels of fine particle mass, particle number concen- 
AMBIENT AIR POLLUTANTS IN FARM SETTLEMENTS...

trations and black smoke under different be:http:/ / www.fao.org/ docrep/ 005/

ventilation conditions. Journal of Expo- y4252e/ y4252e13a.htm

sure Analysis and E nvironmental E pidemiology $14: 275-283$

Federal Environmental Protection Agency (FEPA) 1991. Nigerian Standards on En-

Dungan, R.S., Leytem, A.B., Verwey, S.A., Bjomeberg, D.L. 2010. Assessment of bio-aerosols at a concentrated dairy operation. Aerobiologia 26:171-84

Dunn, R.R., Fierer, N., H enley, J.B., Leff, J.W., Menninger, H.L. 2013. Home life: factors structuring the bacterial diversity found within and between homes. PloS one 8(5): e64133. D OI:10.1371/ journal.pone.0064133

Dusenge, M.E., Duarte, A.G., Way, D.A. 2019. Plant carbon metabolism and climate change: elevated CO 2 and temperature impacts on photosynthesis, photorespiration and respiration. N ew Phytologist, 221(1), 32-49.

Eisenberg, S.W.F., Nielen, M., Santema, W., Houwers, D., Heederik, D., Koets, A. P. 2010. Detection of spatial and temporal spread of subsp. in the environment of a cattle farm through bio-aerosols. Veterinary Microbiology 143(2-4): 284

Gilbert, N. 2012. O ne-third of our greenhouse gas emissions come from agriculture. $\mathbf{N}$ ature, 31, 10-12.

Grzyb, J., Lenart-Boroń, A. 2019. Bacterial bioaerosol concentration and size distribution in the selected animal premises in a zoological garden. Aerobiologia 35: 253268

Food and Agriculture Organization (FAO) 2015. World agiaulture tonards 2015/ 2030: anFAO perspetive FA O . A vailavironmental Parameters and Control, Nigeria A manual guide for Environmental usage Available from faolex.fao.org/ docs/texts/ nig18380.doc

Harizanova-Bartos, H., Stoyanova, Z. 2018. Impact of agriculture on air pollution. CBU Intemational Conference on Innovations in Science and Education March 21-23, Prague, Czech Republic

Hinz, T. 2002. PM in and from agricultureIntroduction and overview: Institute of Technology and Biosystems Engineering, J Agric Eng Res 70 (1):111-118

Ingle, S.T., Pachpande, B.G., Wagh, N.D., Patel, V.S., Attarde, S.B. 2005. Exposure to vehicular pollution and respiratory impairment of traffic policemen in Jalgaon City, India. Industrial health 43(4), 656662.

Jager, A.C. 2005. Exposure of poultry farmworkers to ammonia, particulate matter and microorganisms in the Otchefstroom District, South Africa. MSc Dissertation, NorthWest University, South Africa

Kalisa, E., Archer, S., Nagato, E., Bizuru, E., Lee, K., Tang, N., Pointing, S., Hayakawa, K., Lacap-Bugler, D. 2019. Chemical and biological components of urban Aerosols in Africa: current status and knowledge gaps. International journal of environmental research and public health, 16(6), 941.

Karambelas, A., Holloway, T., Kinney, P.L., Fiore, A.M., DeFries, R., Kiesewet- 
ter, G., Heyes, C. 2018. Urban versus rural health impacts attributable to $\mathrm{PM}_{2.5}$ and $\mathrm{O}_{3}$ in northern India. E nvironmental Research Letters, 13(6), 064010.

Karimi, M. 2017. 5 Tips to successfully manage poultry house ammonia levels. Available at: https:/ / www.biomin.net/ en/ articles/5-tips-to-successfully-managepoultry-house-ammonia-levels/. Accessed on 4th March, 2019.

Li, Y., Leung, G.M., Tang, J.W., Yang, X. 2007. Role of ventilation in airborne transmission of infectious agents in the built environment-a multidisciplinary systematic review. Indoor Air 17: 2-18

Morakinyo, O.M., Ana, G.R.E.E., Hammed, T.B., Adejumo, M. 2015. Indoor air quality and perceived health effects experienced by occupants of an office complex in a typical tertiary institution in Nigeria, Science Journal of Public H ealth 3 (4): $552-558$

Mostafa, E., Nannen, C., Henseler, J., Diekmann, B., Gates, R., Buescher, W. 2016. Physical properties of particulate matter from animal houses-empirical studies to improve emission modelling. E nvironmental Science and Pollution Research, 23(12), 12253-12263.

Napoli, C., Marcotrigiano, V., Montagna M.T. 2012. Air sampling procedures to evaluate microbial contamination: a comparison between active and passive methods in operating theatres BMC Public $\mathbf{H}$ ealth 12:594

Ogun State Government (OGSG) 2017. Available: http:/ / wwwogunstategovng/ ogun-state-profile/ Assessed 25th February,
2017

Ohimain E.I., Izah S.C. 2013. G aseous emissions from a semi-mechanized oil palm processing mill in Bayelsa state, Nigeria.

Continental Journal of Water, Air and Soil Pollution 4(1): 15 - 25

Ojekunle, Z.O., Jinadu, O.0.E., Afolabi, T.A., Taiwo, A.M. 2018. Environmental Pollution and Related Hazards at Agbara Industrial Area, Ogun State. Scientific Reports, 8(1), 1-8.

Oyebanji, F.F., Adeofun, C.0., Adedeji, O.H., Ekpo, U.F., Oguntoke, O., Ojekunle, O.Z. (2013) Assessment of respiratory health impact of fuel-wood utilization on exposed rural women in Odeda, Southwestern, Nigeria. Global Journal of Science F rontier R esearch (H) 13:4(1), 23 $-30$

Oyebanji, F.F., 0 guntoke, $0 ., 0$ jekunle, 0.Z., Adeofun, C.0., Adedeji, 0.H., Ekpo, U.F. 2016. Seasonal and Spatial A nalysis of Air Pollutants Emissions from FuelWood Utilization in Selected Rural Communities within O deda LGA, Nigeria. Global Joumal of Science Frontier Research 16 (3) Version 1: 32 - 42

Power, A.L., Tennant, R.K., Jones, R.T., Tang, Y., Du, J., Worsley, A.T., Love, J. 2018. Monitoring impacts of urbanisation and industrialisation on air quality in the Anthropocene using urban pond sediments. F rontiers in E arth Science, 6, 131.

Raaschou-Nielsen, 0., Andersen, Z.J., Beelen, R., Samoli, E., Stafoggia, M., Weinmayr, G., Hoffmann, B., Fischer, P., Nieuwenhuijsen, M.J., Brunekreef, B. and Xun, W.W. 2013. Air pollution and 
AMBIENT AIR POLLUTANTS IN FARM SETTLEMENTS...

lung cancer incidence in 17 European cohorts: prospective analyses from the European Study of Cohorts for Air Pollution Effects (ESCAPE). The Lancet O ncology, 14(9), 813-822.

Rashid, G., Hekmat, R., Nejat, L.A., Payam, J., Farzad, J. 2013. Analysis and comparison exhaust gas emissions from agricultural tractors. International Journal of Agriculture and Crop Sciences 5(7), 688.

Rohila, A.K., Ansul, M.D., Kumar, A., Kumar, K. 2017. Impact of agricultural practices on the environment. Asian Journal of Microbiological Biotechnology and E nvironmental Science 19 (2): 145148

Samadi, S., Wouters, I.M., Heederik, D.J.J. 2013. Review of bio-aerosol exposures and associated health effects in veterinary practice. Ann Agric E nviron Med. 20 (2):206-221

Schulz, J., Seedorf, J., Hartung, J. 2005. Estimation of a safe distance between a natural ventilated broiler house and a residential dwelling In: Krynski, A., Wrzesien, R. eds: Proc, Volume 2, XIIth Internat Congress on Animal Hygiene of the ISAH Intemational Society for Animal Hygiene and Environment, Warsaw, Poland, 04080905, 41-45

Seedorf, J. 2004. An emission inventory of livestock-related bio-aerosols for Lower Saxony, G ermany. Atmospheric E nvironment 38: 6565-6581

Sowiak, M., Bródka, K., Buczyńska, A., Cyprowski, M., Kozajda, A., Sobala, W., Szadkowska-Stańczyk, I. 2012. An assessment of potential exposure to bio-aerosols among swine farmworkers with particular reference to airborne microorganisms in the respirable fraction under various breeding conditions. Aerobiologia, 28(2), 121-133.

Stryjakowska-Sekulska, M., Piotraszewska-Pająk, A., Szyszka, A., Nowicki, M., Filipiak, M. 2007. Microbiological quality of indoor air in university rooms. Polish Journal of Environmental Studies 16(4): 623-632

United States Environmental Protection Agency (USEPA) 2009. Air Q uality Index: A guide to air quality and your health. Research Triangle Park, NC: U.S. EPA, Office of Air Q uality Planning and Standards. EPA456/ F-09-002

Wemedo, S.A., Ede, P.N., Chuku, A. 2012 Interaction between building design and indoor airborne microbial load in Nigeria. Asian Journal of Biological Sciences 5: $183-191$

World Bank Group 2019. https:/ / data.worldbank.org/ indicator/

SP.POP.GROW (Accessed 15th October, 2019).

World Health Organization (WHO) 2000. Guidelines for Air Q uality.G eneva

World Health Organization (WHO) 2002. Guidelines for concentration and exposureresponse measurements of fine and ultra fine particulate matter for use in epidemiological studies, Geneva, Switzerland

World Health Organization (WHO) 2005. Air quality guidelines - global update 2005 http:// www.who.int/ phe/ health topics/ outdoorair/ outdoorair acg/en/ Accessed on April, 20th 2018 
F. F.OYEBANJI, G.R.E.E., ANA, Y. MIJINYAWA AND Y. A. TIJANI

Winkel, A, van Riel, J.W., van Emous, matter from intensive pig production at a R.A., Aamink, A.J.A., Groot Koenkamp, large farm in north China. Aerosd and Air P.W.G., Ogink, N.W.M. 2016. Abatement Quality Reserch16:79-90 of particulate matter emission from experimental aviary housings for laying hens by Zucker, B.A., Trojan, S., Müller, W. 2000. spraying rapeseed oil. Poultry Science 95 Air-borne gram-negative bacteria flora in (12):2836-2848 animal houses. Jaumal of veteinary mediane B, Infetias diseses and veteinary public helth 47

Xu W, Zheng $K$, Meng L, Liu $X$, (1):37-46.

Hartung E, Roelcke M, Zhang, F. 2016.

Concentrations and emissions of particulate

(Manuscipt reeived 23rdMarch, 2020; accepted 29thJume, 2020). 